\title{
Georges Frédéric Parrot and His Friendship with Two Great Men-The French Scientist Georges Cuvier and Emperor Alexander I of Russia
}

\author{
Epi Tohvri \\ Tallinn University of Technology Tartu College, \\ Puiestee 78, \\ Tartu 51008, Estonia \\ E-mail: epi.tohvri@taltech.ee
}

\begin{abstract}
Georges Frédéric Parrot was one of the developers and spokesmen of the liberal educational concept of the Enlightenment era in the Russian Empire in the first part of the 19th century. He was born in Montbéliard, Duchy of Württemberg. Parrot studied at Hohe Karlsschule in Stuttgart, and spent his tutorial years in Normandy, France. His best friend Georges Cuvier followed the same path. The first part of the article deals with the educational ideas of Physiocrats, especially those of Pierre Samuel Dupont de Nemours, which influenced the state-run education systems in the PolishLithuanian Commonwealth, in Russia, and also in America. In 1802, Parrot became a personal friend of Emperor Alexander I of Russia. Parrot introduced to the Emperor the concept of university which dealt with serfdom and its relation to the university as well as human culture and social welfare. Parrot was the person to draft the University of Tartu's foundation document, and he was responsible for making the institution accessible to representatives of all social groups. The university became the enlightened centre of the educational district. Parrot's main interest was related with the state-run parochial school system. The education paradigm of Physiocrats laid the basis for the new university concept of the Enlightenment era, which consisted in five important points, and it was spread to the both sides of the Atlantic.
\end{abstract}

Keywords: Enlightenment era, Emperor Alexander I, Frédéric-César de La Harpe, Georges Frédéric Parrot, Georges Léopold Chrétien Frédéric Dagobert Cuvier, Montbéliard, new university concept, Pierre Samuel Dupont de Nemours, Physiocracy, Polish-Lithuanian Commonwealth Commission for National Education (Komisja Educacji Narodowej, KEN) 


\section{The similar youths of Parrot and Cuvier}

Georges Frédéric Parrot's birth town Montbéliard (Mömpelgard in German) is situated in the French department of Doubs about 400 kilometres northeast of Paris, next to the Swiss border. Since 1397 the city belonging to the former Duke of Burgundy went to the Duchy of Württemberg through a dynastic marriage and during reformation turned into a protestant Lutheran dominated Frenchlanguage island in the neighbourhood of powerful catholic France. Language and nation were not prioritised back then, it was more important to belong to a certain ruler, but also community peculiarities. Thereby, people of Montbéliard did not consider themselves French, German or Swiss. They were what they were-citizens of Montbéliard—and from this originated their value and originality. From France, they had inherited their clear and precise language and due to their Lutheran religion, they were deeply interested in education. This kind of living environment on the border areas determined openness to different cultures, practices and languages (Mülhenheim, 1974, pp. 446-454).

It is important to note that the Duchy of Württemberg possessed close relations with the Russian Empire in the 18th-19th century. The Duke of Württemberg Friedrich II Eugen established the first dynastic union by marrying his daughter Sophie Dorothea to Russian Emperor Paul I in 1776. After arriving to Russia, Sophie Dorothea became Orthodox and changed her maiden name to Maria Feodorovna. This smooth marriage, filled with plenty of children, established a tight association between the two countries for more than half a century. In the 18 th century, it was common that also the noblemen and artisans from the region belonging to the ruling pair's family members could expect new opportunities at the royal court. The people who stayed or had lived in Russia for a while were nicknamed les Russiens at home, disparating them from les Russes. According to an account from 1794, 285 people from Montbéliard had moved to Russia and, at the end of the 18th century, the numerous French or Francophone community in all of Russia was roughly composed of $10 \%$ of citizens from Montbéliard (Mézin, 2004, pp. 659-673).

Georges Frédéric Parrot was born in Montbéliard on July 5 (June 24), 1767 as the youngest child of the town's surgeon and the main inspector of the Duchy of Württemberg road and agriculture Jean Jacques Parrot (1721-1795). He received higher education at Hohe Karlsschule (Karl's High School) in Stuttgart between 1782 and 1786. Hohe Karlsschule was a sort of an experimental school of higher education as the division of faculties was missing the faculty 
of theology. Accepted students could choose between the faculties of law, medicine, philosophy, military, fine arts, and Cameralism as discipline, which included finances and economy. The curriculum was based on modern study fields in classes and the reputation of this school spread all over Europe due to its contemporary modern and comprehensive curriculum, which could only be challenged by the University of Göttingen.

Parrot established the most cordial relationships with Georges Léopold Chrétien Frédéric Dagobert Cuvier (1769-1832), a Montbéliard native, who established his name in the history of science as the researcher of fossils and the creator of the catastrophism theory, while Parrot also played a small role in this success story (Fig. 1).

In Parrot's memories, he and his childhood and school-time friend had a lot in common-both originated from the small Montbéliard town, were born prematurely, had close relationships with their mothers and were mentally gifted. Hereafter we see that both men achieved high state positions as the counsellors of science and education at royal courts. But chance has an important role to play in life: Cuvier was able to realise his talents in Paris, the cosmopolitan centre of the world, but Parrot lived in the peripheral town of Tartu and the capital of the Russian Empire St. Petersburg, remaining almost unknown in France up until now. The first to draw parallels to this notion was professor Jānis Langins from the University of Toronto (Langins, 2004, pp. 297-320). ${ }^{1}$

Shortly before graduating from the university, Georges Frédéric Parrot was offered a tutor's position by the family of the governor of Lower Normandy, protestant Duke d'Hericy, whose only son Achille was ten years old. During these times in Normandy, the French Physiocrats were reorganising agriculture and this region became a successful polygon of experimentation for the Physiocrats. In 1762, the agriculture and trade union (Société d'agriculture et de commerce de Caen) was established in Caen and one of its active members Abbé Gervais de La Rue was one of the closest friends of young Parrot with whom he maintained correspondence until the 1820s (Bibliothèque de l'Institut de France, No. 51).

Physiocrats paid great attention to improving the rights and economic welfare of peasants, but inside the Physiocrats' economic theory Pierre Samuel Dupont

The first to discover the correspondence between Parrot and Cuvier in the Cuvier's fund of the Bibliothèque de l'Institut de France was Jānis Langins, historian of technology and professor at the University of Toronto, and he titled his article very accurately: 'Diverging parallel lives on science: Unpublished correspondence from Georges-Frédéric Parrot to Ceorges Cuvier'. Hereby, I cordially thank Jānis Langins for being one of the supporters of my academic career. 


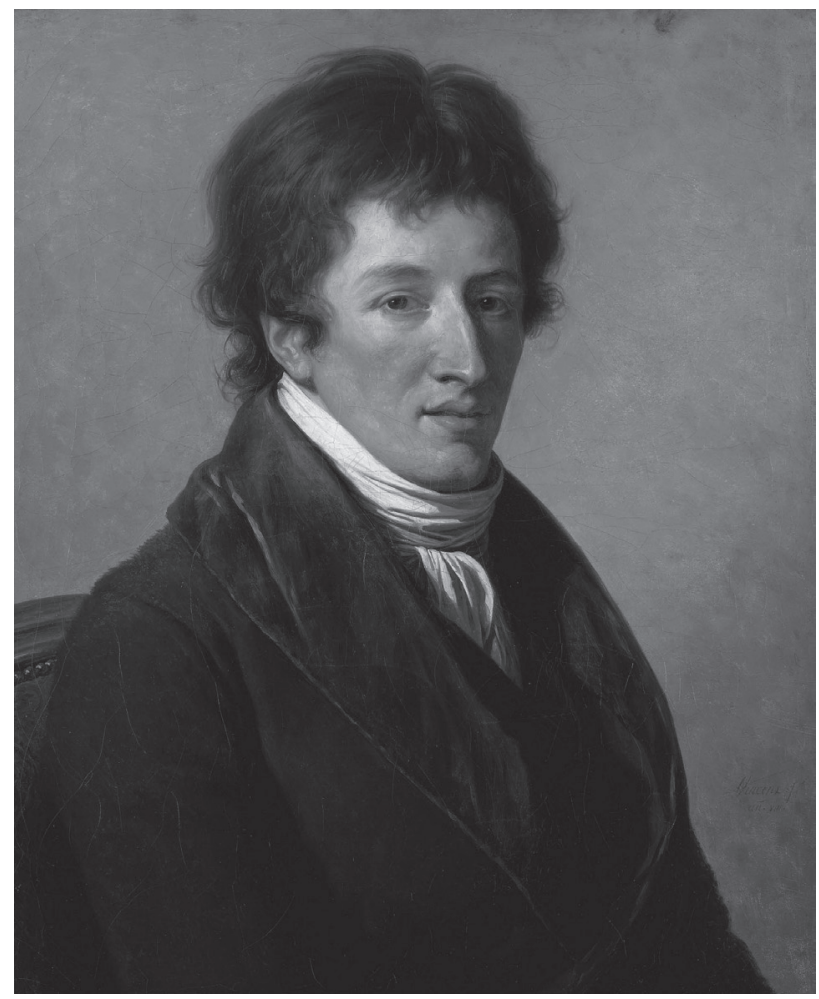

Figure 1.

Georges Cuvier.

Painting by

François-André

Vincent. Wikimedia

Commons, n.d.

de Nemours (1739-1817) formulated a new educational discourse, which is considered an original part of the Physiocrats' economic program. ${ }^{2}$ Dupont de Nemours did not directly deal with education theory but gave practical recommendations on how to spread education in towns and villages and how to plan new universities which could be beneficial to the development of the society, phrased in the encyclopaedia of the French Enlightenment era as spreading "useful knowledge" to all layers of the society.

Dupont de Nemours emphasised that the goal was to establish a federally operating network of primary schools in both villages and cities, whereas the schools were to be given a new content and better material instruments. Dupont stressed that schools must teach religion directed by the ethics and the state must

2 Pierre Samuel Dupont de Nemours (1739-1817), a French writer, economic theorist and statesman, whose written work Physiocratie, Ou Constitution Naturelle du Gouvernement le Plus Avantageux au Genre Humain (1768) had considerable influence on Adam Smith. Dupont de Nemours counselled several rulers, including Baden Margrave Karl Friedrich, the Polish King Stanisław August Poniatowski, and the third President of the USA Thomas Jefferson in educational affairs. 
stand higher than the church. Although the clergy also possessed pedagogical competence, they could only be hired to newly established schools with yearlong contracts because this way the schools were free to decide how long they wanted the clergyman to work with them.

The educational ideas of Physiocrats were brought to life by the Commission for National Education (Komisja Educacji Narodowej, KEN), created in 1773 in the Polish-Lithuanian Commonwealth (Rzeczpospolita). The Commission had an entirely unique ministry of education in Europe, which initiated the modernisation of the former school system. Pierre Samuel Dupont de Nemours was invited to Poland upon the invitation of Prince Adam Kazimierz Czartoryski in order to help building up the Polish educational system, and he became the personal advisor and secretary of King Stanisław August Poniatowski (Vardi, 2012, pp. 239).

In 1783, the Commission for National Education presented the Act of the National Education for the Schools and Academic Institutions of Rzeczpospolita (Ustawy Komisji Edukacji Narodowej, 1902). Of the 25 paragraphs of the Act, the first one deserves immediate attention as it states that the Commission for National Education creates a new social class in the society-the Academic Class (stanu akademickiego). It is one of the most important decisions made. A new academic class would be mostly autonomous and was guaranteed a higher societal status and income.

In 1800, Pierre Samuel Dupont de Nemours recommended a similar educational plan to the third President of the USA Thomas Jefferson. As for universities, Dupont de Nemours proposed a new structure and construction which would respond to the needs of higher science specialisation colleges and added that the word 'university' comes from Europe, where it usually marks an institution divided into four classic faculties, of which he was most critical about the faculty of philosophy since it does not teach anything useful for life. (Du Pont de Nemours, 1923, pp. 121-124)

Influenced by the education paradigm of Physiocrats, Denis Diderot, a French Enlightenment era figure and encyclopaedist, wrote a similar education plan to the Russian Empire on the request of Catherine the Great. Diderot wrote: "University is a school, the doors of which have to be open to all the children of the state. And where teachers paid by the state teach all the basics of science. I say without differentiating because it would be evil and absurd to discriminate the lower classes of the society." (Diderot, 1775-1776) 


\section{Parrot as the representative of the French science paradigm in Russia}

When young Parrot arrived from Stuttgart in Paris in 1786, this metropolis was the intellectual universe in almost every field of life. Eighteen-year-old Parrot spent long hours in the library of the French Royal Academy of Sciences to familiarise himself with the newest accomplishments in the field of mathematics and physics. During the two tutoring years in Normandy he repeatedly visited Paris and met several famous scientists of the time, the most notable of whom was the director of the Paris Observatory astronomer Joseph Jérôme Lalande (1732-1807). Parrot met Lalande at the Lycée de Paris science school, giving science lectures to the people of the city, organised by the Les NeufSourr's scientific lodge. At one of the arithmetic courses Lalande took notice of the young man for his knowledge and invited Parrot to become involved in arithmetic. Parrot took the ambitious goal of compiling an algebra textbook Cours élémentaire d'arithmétique, which was finished by the end of 1787 . After sending the book to Joseph Jérôme Lalande to review, Parrot waited for nearly half a year before finally receiving a positive answer:

I approved the manuscript a while ago but I did not know who to send it back to. I find that it is very good, clear and full of spirit and knowledge; I have no criticism on it. With the utmost of respect, your humble De la Lande in your service. Collège Royal, 27 June 1788. (LVVA, 1788, p. 189, Fig. 2)

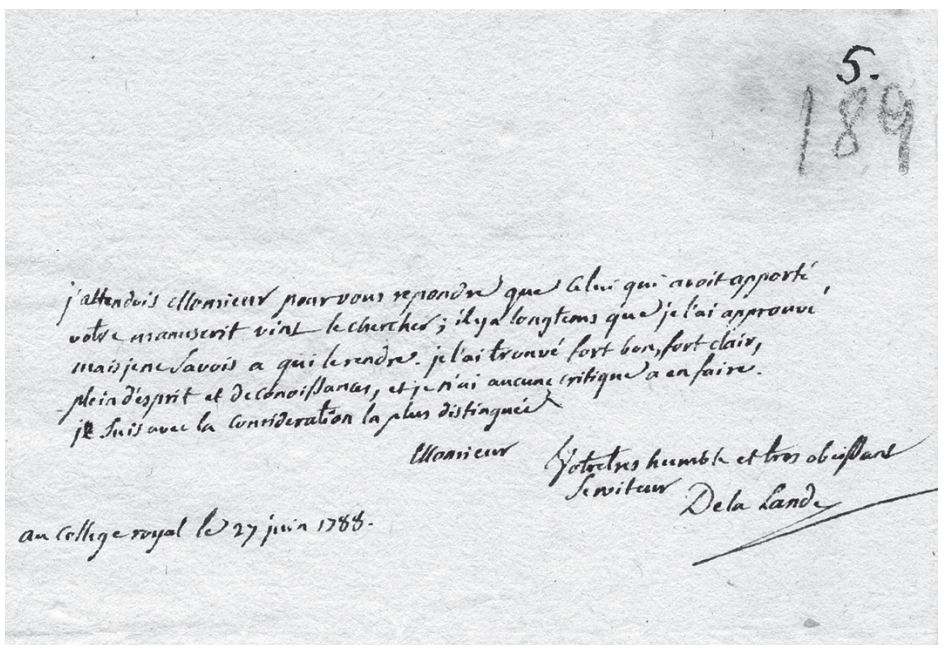

Figure 2.

Joseph Jérôme Lalande's letter to Parrot, autograph. National Archives of Latvia. 
Parrot participated in the lectures of, among others, the chemist Antoine François, Comte de Fourcroy, and the physicist, philosopher, mathematician and politician Marie Jean Antoine Nicolas de Caritat, Marquis de Condorcet, keeping academic correspondence with them later on after being in Livonia (Bibliothèque de l'Institut de France, No. 46).

In the spring of 1788 , the loved father of Parrot's fiancée died and Parrot returned to her in Karlsruhe. But he had to find a replacement fast. He made a proposition to his friend Georges Cuvier, who was just about to finish Hohe Karlsschule in Stuttgart and he agreed to replace Parrot. Cuvier's later destiny is well known in science history. But Parrot's marriage resulted in two sons, Johann Jacob Wilhelm Parrot (1790-1872) and Johann Jakob Friedrich Parrot (1791-1841) (LVVA, n.d., p. 188). The younger son Friedrich Parrot became a famous mountaineer and the

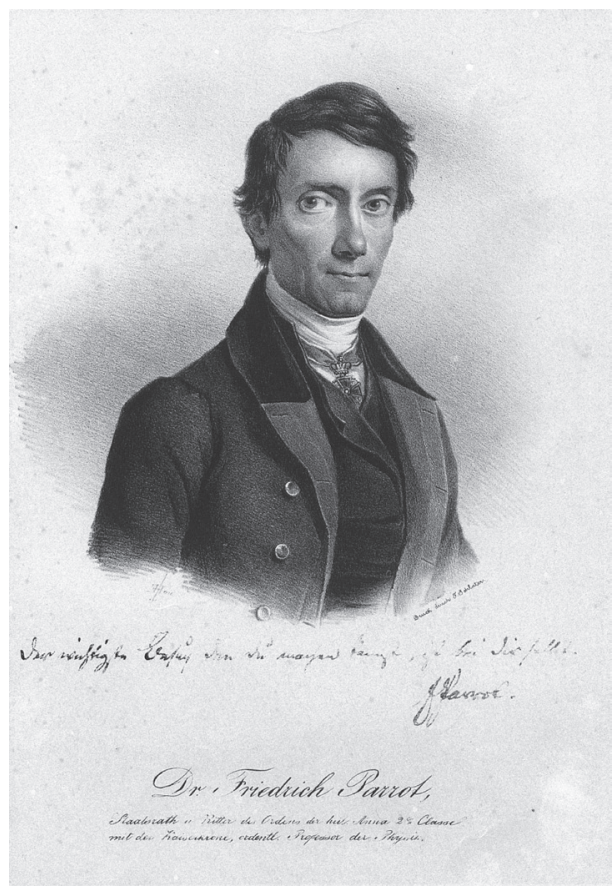

Figure 3. Friedrich Parrot, the famous naturalist and explorer who inherited his father's looks and intellect. The portrait dated to 1831 with the second class Order of Saint Anna for conquering Mount Ararat bearing a signature and the motto: "The greatest success you can achieve depends on yourself" (Tartu University Library, ÜR 883) conqueror of Ararat in 1829. Friedrich Parrot obtained a doctor of medicine degree from the University of Tartu in 1814 and joined the victorious Russian army in its conquest of Europe as the First Degree Military Staff surgeon. After conquering Paris, Friedrich Parrot stayed in Paris for the year 1815 and interacted with remarkable scientists such as Alexander von Humboldt (1769-1859), who became his supporting friend and mentor for the rest of his life. He also met his father's old friend Georges Cuvier and the French astronomer, physicist and mathematician Jean-Baptiste Biot (1774-1862) (Parrot, 1843, pp. 110-122, Fig. 3). 
Unfortunately, Georges Frédéric Parrot's wife Wilhelmine died of tuberculosis in 1792 and after the death of his wife Parrot planned to come to Livonia because his older sister Clémence Marguerite had already arrived to Riga to become a governess. Parrot accepted the position of tutor at the family of Count Karl Eberhardt von Sivers in 1795 in the castle of Ceesis in Livonia. Thereby they were both les Russiens from Montbéliard. Soon Count Sivers offered Parrot the position of science secretary at the established Livonian Charitable and Economic Society (Tohvri, 2013, pp. 11-39). In a letter to his friend Georges Cuvier in Paris from 1800, Parrot describes the pettiness of the Livonian academic scene and the intellectual downturn during the reign of Paul I and the strict censorship. By that time, Cuvier had already become a member of the Institut de France and a professor of natural sciences at College de France. Parrot wrote:

My dear Cuvier, do not be scared by the looks of this letter, it might seem to be originating from another world. No, I am still not on the other side of Styx [river]. I am still on the Earth but I am in the North where the visible and perceptible ice brings everyone not from here to the sleep of death. I have decided to fight this fatal influence by warming my body, my mind and heart thinking about your — and once my own — home land. The French climate, air of freedom and writing to you, as well as Lalande, [Antoine François, Comte de] Fourcroy', [Louis-Bernard Guyton] Morveau' and [Louis Nicolas] Vauquelin are my only tools for staying awake, my existence which would otherwise crumble in this dryness of where I live. (LVVA, n.d., no. 46)

Parrot also mentioned that the friend would remind him to the astronomer Jérôme Lalande. "Please ask him to save this young man, who awakened friendship 13 years ago, when he met him at an arithmetic course and received his appraisal, out of this northern cave of darkness." Parrot was determined to return to Europe, especially Paris, which was and remained his oasis of science, an unattainable ambition for the rest of his life.

The last letter that Parrot sent to Cuvier before Napoléon's wars in Europe is dated to May 1802 and in the letter Parrot writes that a university is finally opened in Tartu and he no longer has the necessity to return to Paris, even though this wish still intrigues him. Soon after this letter, Parrot met Emperor Alexander I and found new goals and self-fulfilment in Tartu. Parrot's contact with his childhood friend Georges Cuvier stopped for two decades of the 18th century, but in the Baltic provinces their friendship was known even afterwards. As a member of the Saint Petersburg Academy of Sciences Parrot was still considered a follower of 
French science methods and the friend of the famous natural scientist Georges Cuvier. This becomes evident in Nikolai Pirogov's and Karl Ernst von Baer's memoirs.

So what could have been the reason for their drifting apart? It was the science hegemony of Napoléon's Empire and its opposition with Russia. Because Parrot became a friend of Alexander I and his counsellor in political and education affairs during his liberal ruling period (1801-1812), Georges Cuvier played an important role in Napoléon's Empire. Cuvier still had a brief contact with Parrot in 1810, when Karl Morgenstern (1770-1852), professor of classical philology at the University of Tartu, returned from his long European tour. Cuvier sent his old friend Parrot cordial greetings and as a sign of friendship a publication of the Institut de France which summarised the achievements of French scientists since the post-revolution period until 1808 (Rapport Historique Sur Les Progrès..., 1810). This report was ordered by Emperor Napoléon personally and the creator of the text was the secretary of the Institut de France Georges Cuvier. The main focus of this report was only achievements in the French natural sciences, as it completely disregarded discoveries from Germany, let alone the Russian Empire. Georges Frédéric Parrot read the report sent by Cuvier very carefully and said:

These papers were interesting for me, although their main contents, namely the French science monopoly, was known to me before. By the way, it was not as bad as it seemed based on this report and it can be explained by the notion that this report is sent by an institute troubled in agony, already partly divided into classes and with the fact that it is sent to the Emperor [Napoléon]. By the way, if I had a saying in this, I would have called the final act of the Institut de France to be fair, not some kind of bragging about the progress of itself. To what extent Cuvier was guilty of these sins or how much he was led by the majority can only be asked from himself. Otherwise, his spirit was strong, even though his acts were not always delicate. (TÜR, KHO, 1810, pp. 387-391)

The scientists of other countries also witnessed all of this and found it unfair that only the French scientific accomplishments were presented. The main reason could have been that French science did not accept the natural-philosophical method practised by most of the German natural scientists, but in reality, this report imposed a blockade against the scientific accomplishments, articles and books of other countries, just as had been done on the political arena. In the German science world this situation was described by the phrase: "French scientists were sadly little informed about the German-language science..." 
(Daston, 1990, pp. 104-105) At the same time the rest of Europe started to believe that in France science was honoured and a scientist was a well-respected figure, and that the profession of a scientist was also useful in the economic sense. This way the Napoleonic state-funded science model and rivalry started to spread to other European countries.

\section{Parrot as a personal friend and advisor to Emperor Alexander I}

Young Emperor Alexander I (1777-1825) stepped to the throne after a coup d'état on the night of 11 March 1801, but soon after he faced the reality that education and sciences were abandoned in his country. The St. Petersburg Academy of Sciences still stood on the fame of the mathematician Leonhard Euler; the Moscow University gave barely a hundred graduates to state service every year. Teaching was laid on the shoulders of foreign professors, and science was made in French and German and had no effect on the Russian Enlightenment in any way. Miserable teachers who had no authority in the eyes of students taught at lower-level schools. This is how the bad situation was described by Prince Adam Jerzy Czartoryski, friend of Alexander I and his Secret or Private Committee member (Memoirs..., 1888, p. 307, Fig. 4).

Alexander I soon gathered his friends from the Private Committee to discuss plans to reform the Russian Empire. During the same time the former tutor of Alexander, Frédéric-César de La Harpe rushed to St. Petersburg. He arrived in August 1801 and the Emperor welcomed his teacher warmly, naming him a cordial friend and mentor. They started meeting every day in the court or incognito at La Harpe's place. La Harpe wrote down the contents of their conversations in the form of an analysis (mémoire) ${ }^{3}$ and presented the Emperor questions for discussing before the Private Committee. In ten months, La Harpe sent the Emperor 71 letters with his proposals (Correspondance..., 1978, p. 25). Soon tensions between the Private Committee and La Harpe emerged. The close friends of the Emperor found that La Harpe's influence on his former student was too strong and La Harpe decided to leave St. Petersburg. But before that he sent Alexander his 20-point report on governance, which contained a remarkable point no. 8 . He tells his old student:

3 The form of mémoire emerged in French writing practice in the 17th century under the reign of the King Louis XIV, being an author's comprehensive analysis of a single topic that the rulers could use to administer their country. 
"Find someone close who is highly educated and honest who will start sending you reports on all interesting topics that should be accounted for in ruling a state." 4

Frédéric-César de La Harpe left St. Petersburg on 8 May 1802. On 22 May, Alexander met Georges Frédéric Parrot for the first time in Tartu. Parrot welcomed the Emperor with a salutory speech which conveyed a message similar to La Harpe's educational principles and Alexander I was fascinated with it. (Käsper \& Tohvri, 2015, pp. 36-50). La Harpe and Parrot probably never met eye-toeye; we also cannot find the name of Parrot in the notes or letters of La Harpe, but Parrot had definitely heard of the Emperor's tutor. Parrot said later on that in the Emperor

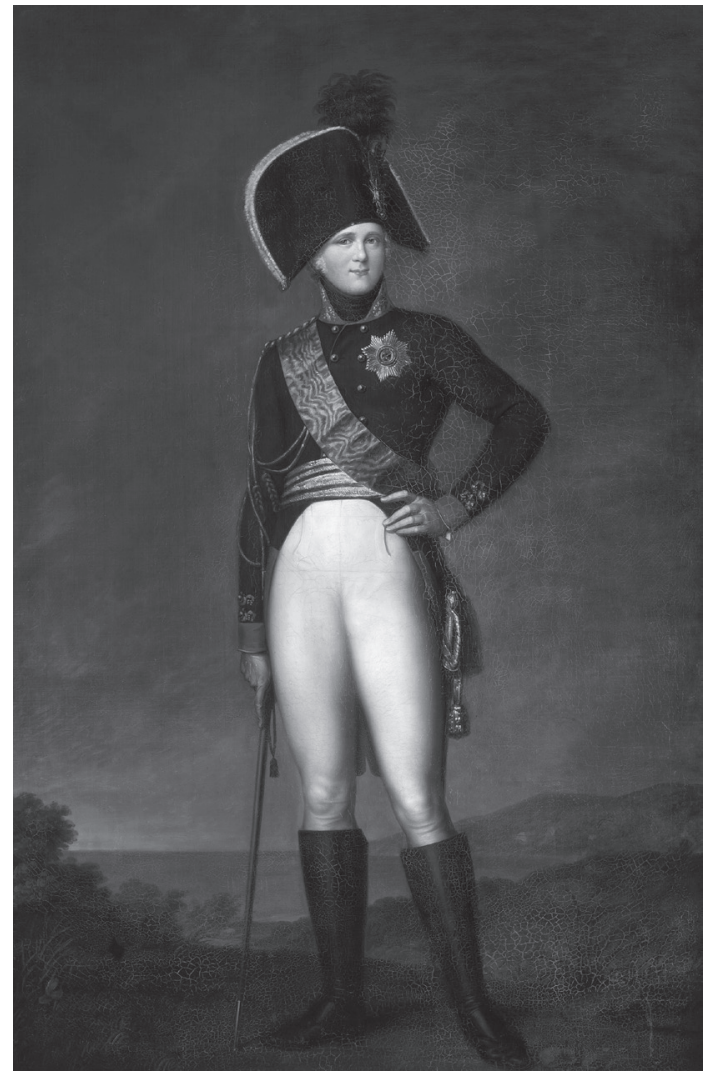

Figure 4. Young Emperor Alexander I.

Painting by Gerhard von Kügelgen from 1801-1803, Estonian Art Museum, M 85. he saw "a tool for making 40 million Russian subjects happy". And confirmed that he would follow the principles and do everything in his power to grow the youth of the University of Tartu the way the Emperor would like to see them, "youth who would love order, but also maintain the good energy that Alexander I could one day use for the benefit of his country." (LVVA, 1805, pp. 1-2). Parrot's close contacts with the Emperor lasted for ten years until the Franco-Russian War in 1812. One of the main reasons for the disruption of the contacts bewteen the Emperor and Parrot was the national conservatism that had emerged in Russia and forced all former foreign liberally-minded advisors, among them Parrot, to withdraw.

4 La Harpe’s letter to Alexander I: Mémoire récapitulatif. Saint-Pétersbourg, 7. Avril, 1802 (Correspondance..., 1978, pp. 538-539) 


\section{Liberal education reform at the beginning of the rule of Alexander I}

In December 1801, there were heated arguments about carrying out the new educational reform between Alexander I and his Private Committee in St. Petersburg. On the Emperor's desk were the best European educational plans of the time. The Emperor's trustee of the time Vasily Karazin, but also La Harpe, supported the French educational model, mostly following the example of the Institut de France established in 1795, in which fields of science were divided into classes. ${ }^{5}$ In fall 1802, Vasily Karazin sent a project of the University of Kharkiv to his companion Georges Frédéric Parrot to get his opinion. Parrot answered him:

The close and friendly ties between us allow me tell you that I have carefully thought through the project of how to establish the University of Kharkiv. And while well aware of this mess around the division of faculties that the representatives of other universities are creating, I can affirm you that I agree with you that universities should be based on the new structure. But as a representative of the University of Tartu, I have had to consider our university's close ties to German universities and therefore I have had to agree to the German model with four faculties, although I would divide the faculty of philosophy into four classes that should cover the need for teaching new fields of science. (Karazin, 1875, pp. 66-76)

Parrot had arrived in Livonia in 1795 and right away he was named head of the Livonian Charitable and Economic Society, the first scientific organisation of the Baltic governments. He sought to incorporate practical education into the curriculum of the university. Because the university's professors and BalticGerman nobilities in the board of trustees were closely connected with the German university culture, the University of Tartu maintained the four faculty system. Parrot suggested changing the structure of the university: instead of the classic German model with four faculties, he wanted to mirror the Institut de France, dividing sciences into classes, giving more diverse opportunities for integrated study and scientific inquiry between the subjects.

According to Parrot's vision, a university should develop into a regional scientific, educational and cultural centre, which should be given special rights so that the

5 In 1795, Institut national de France was divided into physics-mathematics, moral and political science, literature and the arts classes. 
university could build itself a necessary institutional capital in the autocratic society. He had the foresight to understand that the University Board of Trustees (Curatorium) would not open the university for all social classes, but would continue to represent the interests of the nobility, dictate the choice of professors and the organisation of study. Parrot wished that the council of the university would act on the democratic demos principle where each year a new rector is chosen and the council has the competence to choose professors. Meanwhile, the laws and the ruling mentality of the Russian Empire was still not on the level to respect the rights of intellectuals and favour the strengthening of the academic class in the society. For this reason, Parrot wrote to Alexander I on 13 October 1802 about the Founding Act of the University of Tartu (LVVA, 1802b, pp. 50-51p):

Sire! You who love education, and Literary Man (Homme de Lettres). You are convinced in its importance for human culture and its influence on the happiness of the people. To ensure our University's operation in the way it is meant to be, it is necessary to be free of obstacles and win public respect towards the University. Thereby, the University must have privileges compared to other state institutions. Most importantly civil, criminal and police rights. We already have it up to a degree but exactly because of this the University is constantly in contradiction with other institutions of power. (LVVA, 1802b, pp. 50-51p)

It is worth reminding that the Commission for National Education in PolishLithuanian Commonwealth composed the first point of educational law which established autonomy, high status and privileges to the new academic class in order to accelerate and foster education and sciences in Poland and Lithuania. The science historian Juozas Algimantas Krikštopaitis also emphasised this idea in his paper at the 28th Baltic Conference on the History of Sciences in 2017: Polish-Lithuanian Rzeczpospolita's new education law reorganised the Vilnius and Kraków academies and guaranteed them autonomy and a high position in the society, marking the realisation of the French Physiocratic education paradigm in Rzeczpospolita (Krikštopaitis, 2017).

Parrot himself did not study in a classic German university and he objected to the German corporate university mentality, which he expressed in his sharp criticism of the text of the professor of mathematics and natural sciences at the Braunschweig University, Eberhard August Wilhelm Zimmermann's manuscript 'On the outline of the university project established in Livonia' (Zimmermann, n.d.). For Parrot, the main goal of a university was related to the service of human 
culture and the public good, tying the establishment of the university to the abolishment of serfdom and the need for emancipation among the peasants-a theme which Professor Zimmermann never mentioned in his proposals (LVVA, 1802a, pp. 2-9p).

At this point, Georges Frédéric Parrot's actions can be framed applying the concept of 'cultural transfer' (French transferts culturels; German kulturtransfer) (Espagne \& Werner, 1986, pp. 502-510). It marks the people in German cultural space who moved to Paris in the 18th century and mediated their own cultural experiences from the world metropolis of the time through the ideas and cultural contacts brought back with them to their homeland. In studying cultural transfers, it is important to identify enclaves of exchange and their agents. Agents of these transfers are the people who contribute to the movement and dissemination of knowledge and objects from one cultural space to another. They are translators, expatriates or people who move between countries. Moving between different cultures, Parrot brought with him the hybridisation of ideas. Parrot largely remained an observer and analyst while living in the Russian Empire. He did not identify with France of the Napoleonic era or with the German cultural space. He was a citizen of Montbéliard, who arrived to Livonia like many other people from his town. Parrot was well-informed in social, scientific and educational concepts current in the two large cultural spaces-the states of France and Germany.

Thanks to Parrot the Founding Act of the University of Tartu contains an important point that states that the university has the right to accept students of all classes, including native people and foreigners. During the time when the University's Board of Trustees was composed of Baltic-German nobility, this right was not foreseen. However, the Russian university plan, composed by Denis Diderot, already contained the principle that the doors of a university have to be open to all classes because "the proportion of thatched cottages and palaces is ten thousand to one and it is more likely that talents will come from the thatched cottage than from a palace." Parrot conveyed the same message:

Every person is born with his own physical, intellectual and moral capabilities - a Samoyed in his snow hut as well as a sybarite in his golden palace in Paris or St. Petersburg. Everyone has the right to develop his own capabilities given by birth. Both one and the other have the right to be the goal in the order of things (le droit naturel), because nature witnessed this right as the first act by sharing these talents equally. 
Parrot repeated the same idea in the rectorate on 21 September 1803 as he confirmed that the foundation of the building was the act of establishing the university, on top of which an entire structure could be constructed. Such a positive program had never been seen in this region. The Enlightenment had also reached this corner of Europe through the new school organisation. (Parrot, 1803, pp. 7-13)

The newly opened University of Tartu was like a small democratic island surrounded by a town society strictly controlled by the social status. It was the first time when young men from the nobililty, bourgeoisie and peasantry met in the lecture hall. The university was given autonomous privileges by the law, but this privilege also required students to have a clear understanding of their obligations and responsibilities. For this purpose, Emperor Alexander I approved the code of ethics of students of Tartu on 23 August 1803 which helped to regulate the social relations of students inside the university, but also with the townspeople. The rules consisting of six voluminous chapters were published with the same design as the Main Charter of the University and it included new practices of conduct that the students of Tartu's Imperial University had to respect (Vorschriften..., 1803). This law regulating student life no longer involved the corporate rules of former German universities as it already conveyed the new liberal and egalitarian education principles of the Enlightenment era. Parrot also did not support the traditional German corporate establishment and wished to bring the professors and students together into an academic association (Academische Musse), which opened its doors in 1814. After the opening of the University of Tartu, students constituted a harmonious academic family and even the class statuses were overcome-a remarkable accomplishment considering the mentality of a small town. It is known that Georges Frédéric Parrot's relations with students were very friendly and they were sincerely fond of their liberal and energetic professor so that they found the funds to let artist Gerhard von Kügelgen paint a portrait of the first rector of the university. ${ }^{6}$

Parrot was also the spatial planner of the academic campus of the Tartu University. In his vision, the academic buildings should be located on a higher ground on Toome Hill, outside the city centre, and introducing Physiocratic anti-urbanistic principles in Tartu. In Parrot's words, Toome Hill was a "Temple of Wisdom, with its exterior sides altered into a Temple of Nature"- this would have a favourable effect on the imagination of young people and would also inspire future generations to pursue education (RA, EAA, 1803, p. 33). Indeed, Toome Hill evolved into one of the first public urban parks in the Baltic area.

6 See the article by Ingrid Sahk in this journal issue. 

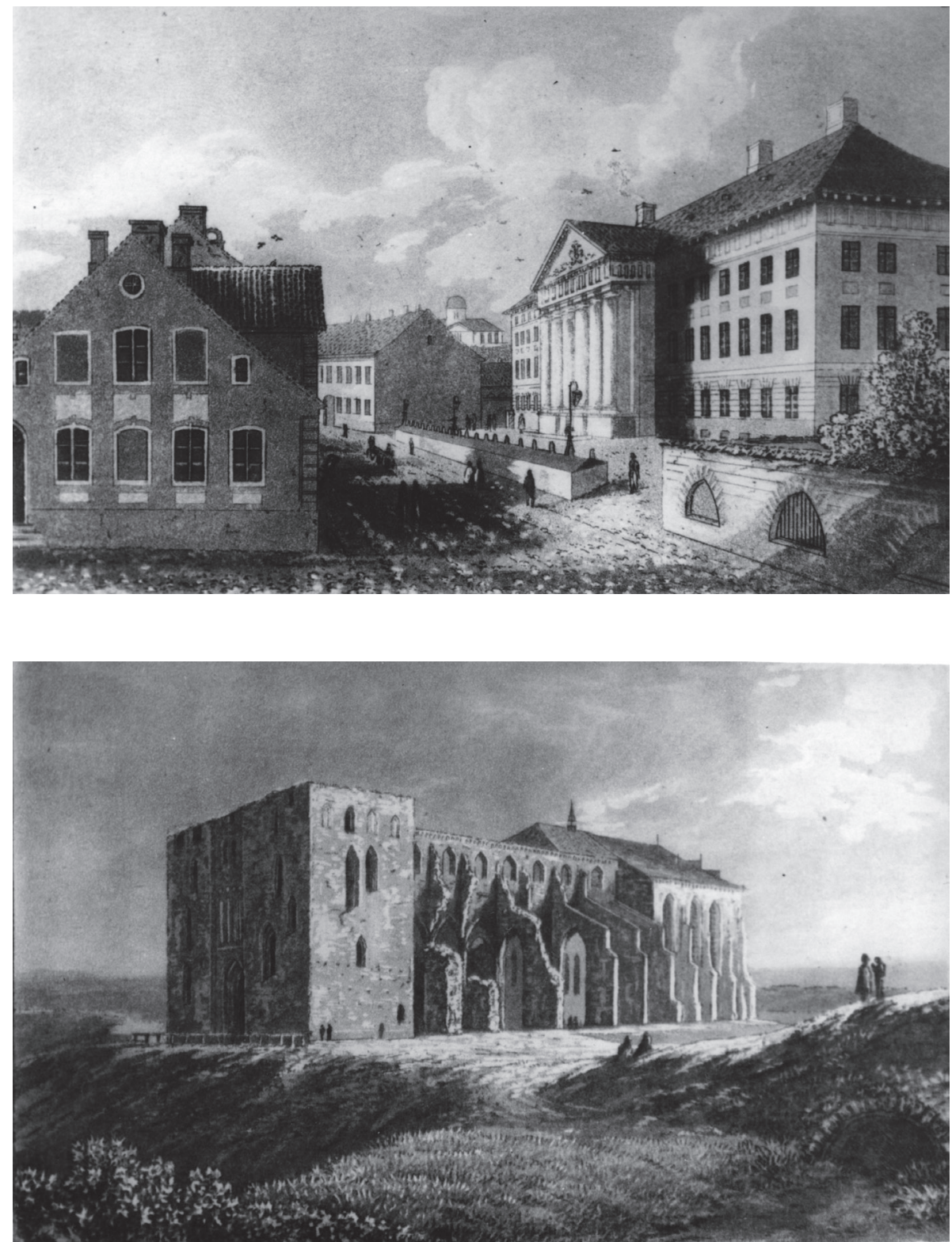

Figure 5. Ensemble of edifices of the University of Tartu in 1821. A view of the main building and other scientific buildings on top of Toome Hill: the library housed in the Dome Cathedral's ruins; the university clinic; the astronomical observatory. Aquatints by August Philip Klara. Estonian History Museum Art Collection, G-67316734. 

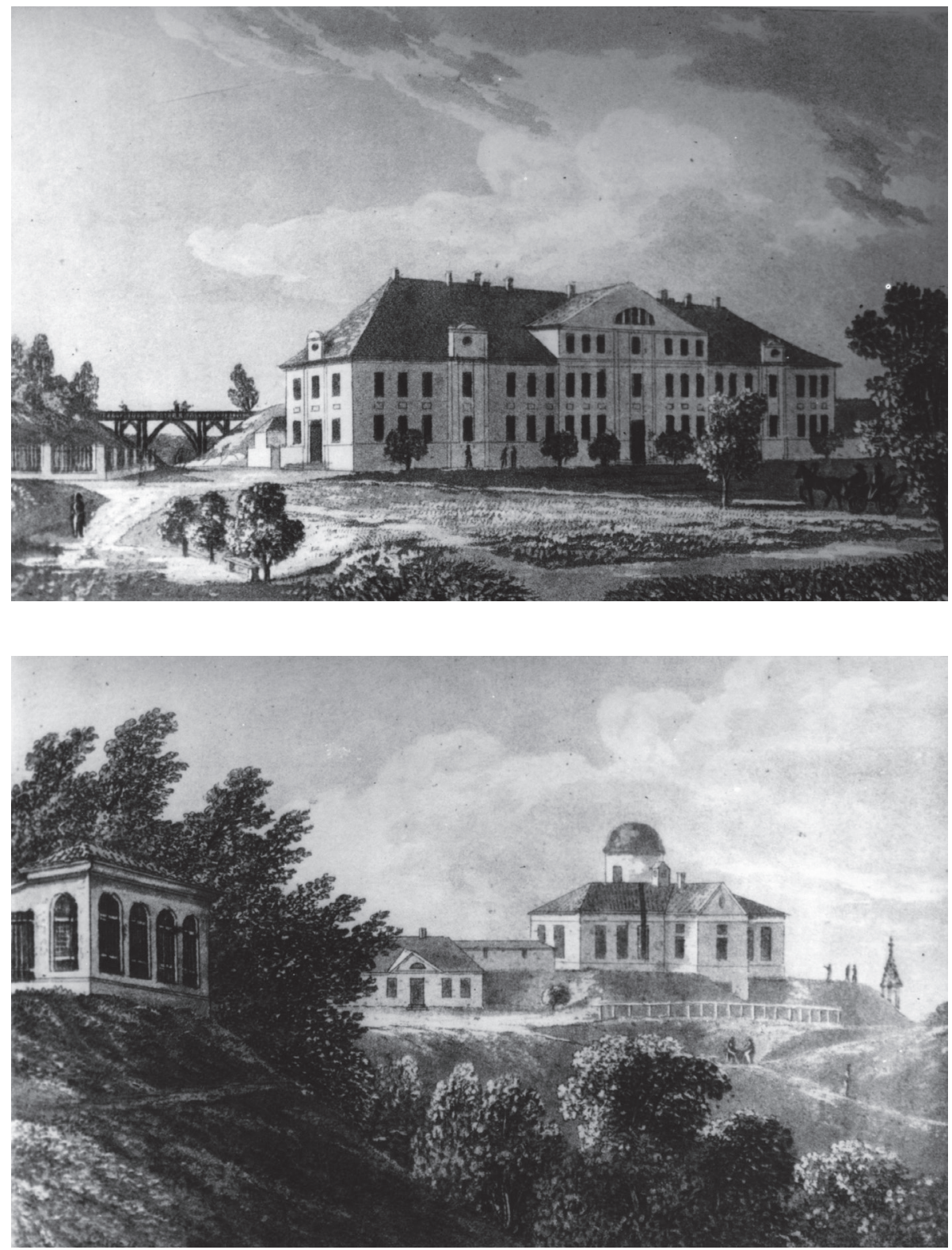
Also, Toome Hill was designed as an "educational city park" where the buildings are located to celebrate the beautiful views of the city and the surrounding landscape. Such a concept - a park open to the public — is evidence of the first signs of democratisation in a society. This is a triumph of a bilateral connection between academic architecture and natural environment (Fig. 5).

On 5 November 1804, Emperor Alexander I presented a decree for the approval of the main charters for the universities of Moscow, Kharkiv and Kazan. The structure of the universities of Vilnius, Moscow, Kazan and Kharkiv responded to the new Enlightenment idea of an university with the following departments: (I) moral and political sciences; (II) physics-mathematics; (III) medical sciences; and (IV) literature and fine arts. The University of Tartu was the only one to preserve the classic German four-faculty university structure (theology, law, medicine and philosophy), which cannot be considered very progressive at the beginning of the 19th century. By the way, the major structural reforms at the University of Tartu, carried out in 2015, followed a similar concept, and replaced the faculties with larger institutes and grouped the institutes under four fields: humaniora, medicina, realia et naturalia, and socialia.

Soon it became evident that establishing the universities of Kharkiv and Kazan was not going as smoothly as envisioned on paper. This threat was already foreseen by Frédéric-César de La Harpe when he told the Emperor that even though there were two universities operating in the Empire (back then in Moscow and Vilnius), it would be more useful to send young people to study in foreign universities. He listed the universities in Göttingen, Jena, Leipzig, Edinburgh, Glasgow, Strasbourg, and Montpellier as the ones where subjects of Russia could receive a good education and then start teaching in the countryside. The means required to finance this idea should be supported by the state. Also, it is necessary to establish the Ministry of Public Education (Ministerstvo narodnogo prosveshcheniia) and a proper plan for its execution. ${ }^{7}$

On 15 September 1803 Parrot wrote the Emperor an analysis (mémoire) on the same topic of how to establish Russian universities. He said that the goal is to give the people state universities and the Enlightenment must reach the Russian people. In order to fulfil this goal, there have to be educated people among the Russian nation to whom teaching was to be trusted. But the first professors have to be schooled abroad and opening Russian universities in Kharkiv and Kazan should be postponed for 6 years, during which educational buildings can be

La Harpe's letter to Alexander I: Observations diverses, No. 1, Saint-Péterbourg, 24. Avril, 1802 (Correspondance..., 1978, pp. 582-583). 
constructed. From both universities, the most capable young students have to be sent to study in German universities. Thirty of the best ones will become professors at the universities, while 60 will become secondary-level teachers (LVVA, 1803, pp. 66-67p). Unfortunately, Alexander I did not take Parrot's proposal into account and the negative results were already seen in 10 years. The universities of Russia were left notably behind the level of the universities in Tartu and Vilnius.

\section{Parochial schools as key institutions in the liberal educational system}

One reason for the lower level of Russian universities was the insufficient construction and substantive backwardness of elementary- and secondary-level schools in Russia. But both Dupont de Nemours as well as La Harpe emphasised that the state's education plan which does not begin with establishing primary school is on a wrong path. Primary education is what guarantees the political and social stability of the society (Albertone, 2004, pp. 129-147). La Harpe travelled around in the areas conquered by Napoléon in Germany and wrote that several new institutions of education had been opened there, including peoples' schools, asking Alexander I directly: "Where are your schools for educating the real people? I hope you will not forget them because they are the basis for everything else. I call you to not forget it - it is the cornerstone of your education."

On 5 November 1804, Emperor Alexander I approved the regulations for the educational institutions subject to universities and the organisation of parochial schools. Developing the related instructions was commissioned from Georges Frédéric Parrot, who eagerly started to put these plans together. Parrot wrote to Alexander I:

Parochial schools, the way I envision them, should be state organised, they should not be affected by local events. If they have already been created, no power can destroy them. Now the time has come to prove how slavery weakens the otherwise so strong state. Only parochial schools can lead to freedom without revolution and bloodshed. Use this opportunity! If the parochial school plan is annulled, then it can be said that for me all other schools lose its point. (LVVA, 1807, pp. 45-45p)

8 La Harpe's letter to the Emperor Alexander I from Dresden 16 July, 1804 (Correspondance..., 1979, p. 150). 
Parrot's parochial school plan received very positive feedback in the Seimas of Lithuania, which was logical because his plan followed the Physiocratic education principles and the Commission for National Education in the PolishLithuanian Commonwealth role model which had been applied in Lithuania for over half a century. Creating a parochial school network in his as well in the entire Vilnius education district was also supported by Prince Adam Jerzy Czartoryski (Lyubzhin, 2015, p. 67). However, the Baltic-German nobility and most pastors worked against the realisation of Parrot's parochial school plan and in Livonia only one parochial school was opened-in Kanepi in 1804. In 1806, the annual report of the School Commission of the University of Tartu informs of already six parochial schools operating in Livonia: four in the Latvian part and two in the Estonian part of Livonia. Parrot wrote about his battles with the local nobility to Alexander I: "I hate enlightened aristocracy even more than political aristocracy. The right to develop a human in his natural environment is the holiest of rights. The devotion to educate intellectuals is so small compared to that of educating people." (LVVA, 1806, pp. 24-25p)

Here it is interesting to bring out the parallel with Parrot's childhood friend and university mate Georges Cuvier, who rose to lead the Napoleonic French educational system. Cuvier became the permanent secretary of the Institut of France, President of the Council of Public Instruction and Chancellor of the Imperial University. In 1809-1810, he fulfilled the important mission of the Napoléon Empire of carrying the title of Grand Master (grand maître de l'Université) and reorganising old academies in Piedmont, Toscana and Genova, which now belonged under the protectorate of Napoléon (Royaume d'Italie) and were part of the French public educational system. In 1811, Cuvier was sent to reorganise the Sapienza University in Rome. Although he was a protestant and a Lutheran, he respected Catholic centres and one can only imagine his complicated task of inspecting these old and respected universities. But he did it with great respect towards the old traditional universities, saying: "who would have the right to obstruct the activity of the noble universities located in Tuscany?"

In 1811-1812, Cuvier was on a similar mission in the Kingdom of Holland and Lower Germany where he familiarised himself with the Dutch school system and was amazed by it. In the Netherlands the Society for Public Welfare (Maatschappij tot Nut van't Algemeen, founded in 1784) had successfully carried on its activities in the spirit of the Physiocratic education paradigm and, as a positive result, a national education law was passed in 1806, which enforced the Dutch school system and strengthened national self-awareness. Cuvier recommended this 
system also to be applied in France (Outram, 1984, pp. 81-82). What Cuvier saw in the Kingdom of Holland convinced him that a true education system must be built from the bottom to up with the state-wide primary and basic school system serving as a broad and strong basis for higher education. Based largely on the things he had seen in the Kingdom of Holland, Cuvier formulated his principles on education. His famous words were:

Give the elementary schools before the political rights; offer the citizens the chance to understand its civil obligations before the state enforces them; teach the citizens their political rights so that they have a part of it with joy-then all changes in the society can be made without causing a larger shock and then every new idea has time to germinate, grow and ripen without shaking up all of the social structure. We should take nature as an example-its development, growth and ripening processes, which would give every social class time to be ready and develop independently. (The Edinburgh Review, 1836, p. 289)

Cuvier's socially sensitive nerve and the ability to turn attention to all the members of the society, their wellbeing and the welfare system turned out to be amazingly similar to Parrot's train of thought in Livonia.

During the second period of rule of Emperor Alexander I, following the FrancoRussian war in 1812, his liberal views were replaced with mysticism and he distanced himself from dealing with the inner issues of the state. During this complicated period, Parrot's resilient and brave actions played an important role in protecting the Tartu educational district from the actions of an obscurant like Mikhail Magnitskiy. Parrot wrote in one of his last letters to Emperor Alexander I:

Sire! Do with me what you want, but I must tell you the truth. You are about to destroy and lose the great honour that the public education system has created during the last twenty years. The public education system that I offered you, but which sadly only realised in the Tartu educational district, gained great and continued appraisal in Europe. And if I was discontent with anything, it is that it was not brought into life in its full extent and all over Russia. (LVVA, 1824, p. 34)

The Physiocratic educational plan reshaped the structure and meaning of the university, but also provided a well-functioning lower- and mid-level school system. This idea realised first in the Polish-Lithuanian Commonwealth, then in the Helvetic Republic, Batavian Republic, French Directorial and the Consulate period, in the Margraviate of Baden, and the Electorate of Baden. 
Thomas Jefferson opened the University of Virginia and public schools in the State of Virgina following the same principles. Alexander I implemented a liberal education system in the Russian Empire from 1803 till 1827, whereas Emperor Nicholas I changed this liberal and egalitarian curriculum of the schools.

\section{In conclusion}

The education paradigm of Physiocrats laid the basis for the new university concept first used in its full extent in (re)establishment of the Kraków and the Vilnius Academy, then Russian imperial universities in 1802-1804, and the University of Virginia, founded by Thomas Jefferson in 1817 . The new university concept of the Enlightenment era contained five important points:

1. University must teach useful and practical subjects that are relevant for the period and are closely integrated. The structure of the university must respond to the modern division of subjects.

2. University must be free from a dominating religion, which essentially meant the secularisation of universities as it happened on the level of the society.

3. University must be organised by the state and it is guaranteed autonomy in society.

4. University must be open to all classes of the society, and it will be the learning centre of the public lower-level school system.

5. Academic buildings must be brought away from the local and church centres of power, which are usually situated in the centre of the town. Academic communities must have their own campuses in picturesque natural environments because that is the best way to bring to life the Physiocratic principle of natural law (le droit naturel), guaranteeing democratic and egalitarian relations in the academic environment.

It must be emphasised that the educational discourse of the Physiocratic economic theory has been forgotten nowadays. However, it definitely deserves more attention to put the education discourse back on its honourable pedestal in the humanistic education story of the European Enlightenment era because these ideas were spread all over Europe at the end of the 18th century and Georges Frédéric Parrot was heavily influenced by this discourse. 


\section{References}

Albertone, M. (2004), 'Dupont de Nemours et l'instruction publique pendant la Révolution. De la science économique à la formation du citoyen,' Revue Française d'Historie des Idées Politiques, no. 2(20), pp. 129-174. http://doi.org/10.3917/rfhip.020.0129

Bibliothèque de l'Institut de France (1925), Parrot's letter to Cuvier' from Tartu/Dorpat, 19. April, 1825, Déherain catalogue, Cuvier MS 247, no. 51.

Bibliothèque de l'Institut de France (1980), Parrot's letter to Cuvier, 1800, from Riga to Paris, H. Dehérain, Catalogue du fonds Cuvier, MS 223, no. 46.

Correspondance... (1978), Correspondance de Frédéric-César de la Harpe et Alexandre Ier, publiée Jean Charles Biaudet, Françoise Nicod, vol. 1: 1785-1802, Neuchâtel: Édition de la Baconnière.

Correspondance... (1979), Correspondance de Frédéric-César de la Harpe et Alexandre I'r, publiée par Jean Charles Biaudet, Françoise Nicod, vol. 2: 1803-1815, Neuchâtel: Édition de la Baconnière.

Daston, L. (1990), 'Nationalism and scientific neutrality under Napoleon,' in T. Frängsmyr (ed.) Solomon's House Revisited: The Organization and Institutionalization of Science, Canton, MA: Science History Publications.

Diderot, D. (1775-1776), Plan d'une université pour le gouvernement de Russie ou d'une éducation publique dans toutes les sciences. Écrit de 1775 à 1776 - Publié partiellement en 1813-1814. Complété d'après le manuscrit de l'Ermitage. Retrieved from http:// obvil.sorbonne-universite.site/corpus/critique/diderot_plan-universite\#body-3 [accessed 10 Nov 2018]

Du Pont de Nemours (1923), National Education in The United States of America, Newark, DE: University of Delaware Press.

Espagne, M. \& Werner, M. (1986), 'Deutsch-Französischer Kulturtransfer im 18. und 19. Jahrhundert. $\mathrm{Zu}$ einem neuen interdisziplinären Forschungsprogramm des C.N.R.S.,' in Francia, 13(1985), pp. 502-510.

Karazin, V. (1875), 'Prednachertaniye o Khar'kovskom Universitete, predstavlennoye v Khar'kove polnomu Dvoryanskomu Sobraniyu 29-go avgusta 1802 goda i posluzhivsheye osnovaniyem prigovoru onogo Sobraniya 1 sentyabrya,' Russkaia Starina, no. 5 .

Krikštopaitis, J. A. (2017), 'Enlightenment in the Baltic States and its short temporary recurrences in the history of the 20th Century,' Abstracts of the XXVIII International Baltic Conference on the History of Science 'On the Border of the Russian Empire: German University of Tartu and Its First Rector Georg Friedrich Parrot', 18-20 May 2017, Tartu: Estonian Association of the History and Philosophy of Science \& University of Tartu Museum. 
Käsper, M. \& Tohvri, E. (2015), 'On Georges Frédéric Parrot's French name, origin and rhetoric: the rector's salutory to the Tsar and the context in which it was given,' Tuna, no. 1, pp. 36-50.

Langins, J. (2004), 'Diverging parallel lives on science: Unpublished correspondence from Georges-Frédéric Parrot to Georges Cuvier,' Journal of Baltic Studies, vol. 35, no. 3, pp. 297-320.

LVVA (n.d.), Parrot's personal notes, F 7350, inv. 1, f. 3, p. 188, National Archives of Latvia, Riga.

LVVA (1788), La Lande’s letter to Parrot' from Paris to Caen, F 7350, inv. 1, f. 3, p. 189, National Archives of Latvia, Riga.

LVVA (1805), Parrot's letter to Emperor Alexander I, no. 1/57, Lettre d'amitié. Trait noble d'une étudiant. Klinger. Le 5. Juin. 1805, F 7350, inv. 1, f. 7, pp. 2-3, National Archives of Latvia, Riga.

LVVA (1802a), Examen de l'ouvrage instituté fait par ordre de S. M. l'Empereur de toutes les Russies Alexandre I par la faculté philosophique de l'Université de Dorpat. Chaptre 1. Considerations sur la servitude relativement a l'influence d'une universite sur la culture de l'homme et le bien public, F 4060, inv. 1, f. 1081, pp. 2-9p, National Archives of Latvia, Riga.

LVVA (1802b), Parrot's letter to Emperor Alexander I, no. 4/3, 13 October 1802, St Petersbourg. Première lettre concernant l'acte de foundation de l'université de Dorpat, F 7350, inv. 1, f. 6, pp. 50-51p, National Archives of Latvia, Riga.

LVVA (1803), Parrot's letter to Emperor Alexander I, no. 5/21, ca 15 September 1803, St Petersbourg. Mémoire sur le mode d'etablissement des universités dans l'intérieur, $\mathrm{F}$ 7350, inv.1, f. 6, pp. 66-67p, National Archives of Latvia, Riga.

LVVA (1806), Parrot's letter to Emperor Alexander I, no. 5/75, 2 August 1806, Dorpat. Sur les écoles paroissiales, F 7350, inv. 1, f. 7, pp. 24-25p, National Archives of Latvia, Riga.

LVVA (1807), Parrot's letter to Emperor Alexander I, no. 2/83, 12 January 1807, Sur les écoles paroissiales, F 7350, inv. 1, f. 7, pp. 45-45p, National Archives of Latvia, Riga.

LVVA (1824), Parrot's letter to Emperor Alexander I, no. 3/179, 26 October 1824, Sur le projet d'un nouveau réglement général pour l'instruction publique l'ouvrage de Magnitzky, F 7350, inv. 1, f. 9, p. 34, National Archives of Latvia, Riga.

Lyubzhin, A. (2015), Istoriya russkoy shkoly, Tom II: Russkaya shkola XIX stoletiya, Kniga 1, Moskva: Nikeya.

Memoirs... (1888), Memoirs of Prince Adam Czartoryski and his correspondence with Alexander I. With documents relative to the prince's negotiation with Pitt, Fox, and Brougham, and an account of his conversations with Lord Palmerston and other English statesmen in London in 1832, vol. I, ed. by Adam Gielgud, London: Remington \& Co.

Mézin, A. (2004), 'Une vue générale de l'immigration française en Russie au XVIIIème siècle,' in J.-P. Poussou, A. Mézin \& Y. Perret-Gentil (eds.) L'influence française en Russie au XVIIIème siècle, Paris: Institut d'Etudes Slaves Presses de l'Université de Paris-Sorbonne. 
Mülhenheim, F. (1974), 'Montbéliard et la Russie,' Realités Franc Comtoises, no. 171/17 Année, Décembre.

Outram, D. (1984), Georges Cuvier. Vocation, Science and Authority in Post-Revolutionary France, Manchester: Manchester University Press.

Parrot, G. F. (1803), Rede bei gelegenheit der Publication der Statuten der Univeristät und der Abgabe des Rectorats am 21. sept. 1803, Dorpat.

Parrot, J. J. F. W. (1843), Neuer Nekrolog der Deutschen. Neunzehnter Jahrgang, 1841. Erster Theil, Weimar: Verlag Bern. Fried. Voigt.

RA, EAA (1803), Description des bâtiments dont l'Université de Dorpat à besoin. Parrot's letter to the Emperor Alexander I and Curator Friedrich Maximilian von Klinger: Description of the buildings needed by the University of Dorpat, 402.5.14, pp. 30-33, The National Archives of Estonia, Tartu.

Rapport Historique Sur Les Progrès... (1810), Rapport Historique Sur Les Progrès Des Sciences Naturelles Depuis 1789, Et Sur Leur État Actuel: Présenté Sa Majesté l'Empereur Et Roi, en son Conseil d'état, le 6 Février 1808, par la Classe des Sciences physiques et mathématiques de l'Institut, conformément à l'arrête du Gouvernement du 13 Ventôse an X/ Rédigé par M. Cuvier, Paris: Imprimerie Impériale.

The Edinburgh Review (1836), The Edinburgh Review or Critical Journal for October 1835 January 1836, vol. 17, Edinburgh: Ballantine and Company.

Tohvri, E. (2013), 'Liivimaa Üldkasuliku ja Ökonoomilise Sotsieteedi esimene póhikri ning selle ideelised allikad' [The first articles of Livonian Charitable and Economic Society and its ideological sources], Teadusinnovatsiooni tee praktikasse. Tartu Ülikooli ajaloo küsimusi, vol. XLI, Tartu: Tartu Ülikooli ajaloo muuseum.

TÜR, KHO (1810), Parrot's letter to Morgenstern 1810, F. 3, Mrg. CCCXLII, kd. 6, pp. 387-391, Tartu: Tartu University Library, Department of Manuscripts and Rare Books.

Ustawy Komisji Edukacji Narodowej (1902), Dla stanu akademickiego i na szkoty w krajach Rzeczypospolitej przepisane $w$ Warszawie roku 1783, Warczawa: Naktadem księgarni M. Borkowskiego.

Vardi, L. (2012), The Physiocracy and the World of the Enlightenment, Cambridge: Cambridge University Press.

Vorschriften... (1803), Vorschriften für die Studierenden auf der Kaiserlichen Universität zu Dorpat. MDCCCIII, Dorpat: Gedruckt bey Michael Gerhard Grenzius, Universitätsbuchdrucker.

Wikimedia Commons (n.d.), 'Georges Cuvier' [image]. Retrieved from https://commons. wikimedia.org/wiki/File:Georges_Cuvier_3.jpg [accessed Nov 2018]

Zimmermann, E. A. W. (n.d.), Versuch eines Entwurfs zu einer in Livland zu Errichtenden Universität, Manuscript. 
Epi Tohvri

Dr. Epi Tohvri is an associate professor at the Tallinn University of Technology. She has been Fulbright scholar at Columbia University in New York City, and a visiting scholar at Robert H. Smith International Center for Jefferson Studies, Monticello, USA. Her main research topic is Enlightenment educational ideas applied by Georges Frédéric Parrot and Thomas Jefferson and the interpretations of these educational concepts in the 21st century. 